\section{PENGADAAN TEMPAT} SAMPAH DI

KELURAHAN BONTO

TANGNGA KEC.

TAMALATEA

\author{
Oleh :
}

Nama : Andi Muh Farid

Email :andimuhfarid23@gmail.com

Nim : 9173490310009

\section{Bentuk kegiatan}

Pembuatan tempat sampah

2. Lokasi

Posko KKLP di Kelurahan Bonto

Tangnga Kec.Tamalatea

3. Hari/Tanggal dan Waktu

Sabtu, 03 Oktober 2020 pukul 14:00

4. Peserta yang dilibatkan

Mahasiswa KKLP

\section{Alasan diadakannya}

Kami melihat di beberapa instansi memiliki tempat sampah yang kurang layak bahkan tidak memiliki tempat sampah sehingga kami memilih untuk membuat program kerja ini.

6. Tujuan dan Manfaat Kami mengadakan program kerja ini agar kebersihan tetap terjaga serta membuang sampah pada tempatnya

7. Deskripsi kegiatan Proses pembuatan tempat sampah ini di lakukan oleh seluruh mahasiswa kklp. Kegiatan ini di laksanakan selama beberapa hari , pembuatan tempat sampah di lakukan sebagai upaya menjaga kebersihan pekarangan di setiap instansi yang mana selama ini banyak sampah berserakan di sebabkan tidak tersedianya tempat sampah. 